\title{
SHALLOW-CORE ANALYSIS AND PIT STUDIES AT SIPLE STATION, ANTARCTICA: IMPLICATIONS FOR EXTRACTION OF A 500 YEAR PROXY CLIMATE RECORD
}

\author{
(Abstract) \\ by \\ Ellen Mosley-Thompson, Lonnie G. Thompson and John Paskievitch \\ (Byrd Polar Research Center, Ohio State University, 125 South Oval Mall, \\ Columbus, OH 43210, U.S.A.) \\ and
}

Pieter M. Grootes

(Quaternary Isotope Laboratory, University of Washington, Seattle, WA 98195, U.S.A.)

\begin{abstract}
Two cores, 302 and $132 \mathrm{~m}$ long, were drilled $1.5 \mathrm{~km}$ up-wind from Siple Station $\left(75^{\circ} 55^{\prime} \mathrm{S}, 84^{\circ} 15^{\prime} \mathrm{W}\right)$ during the 1985-86 austral summer. These cores are expected to contain an annually resolvable 500 year record of atmospheric constituents. The entire length of these cores will be analyzed for insoluble particulate concentrations, liquid conductivity, and oxygen-isotope ratios. Anion concentrations $\left(\mathrm{Cl}^{-}, \mathrm{SO}_{4}{ }^{2-}\right)$ will be measured in selected sections. The extraction of a proxy climate history from these cores requires an assessment of the temporal quality and the spatial variability of the preserved record. This paper presents this assessment, which is based upon an extensive investigation of both pit and shallow-core $(20 \mathrm{~m})$ records.

To complement the two deeper cores, eight $20 \mathrm{~m}$ cores were drilled and three pits were sampled. The pits were excavated up-wind of the drill site at distances between 0.5 and $1.0 \mathrm{~km}$. In the central pit, $2.8 \mathrm{~m}$ deep, walls $\mathrm{A}$ and $\mathrm{C}$ (each $1 \mathrm{~m}$ wide) were positioned parallel to the prevailing wind, with wall $B$ ( $4 \mathrm{~m}$ wide) perpendicular to the prevailing wind. The stratigraphy of wall $B$ was mapped and continuous vertical profiles of samples were collected for microparticle concentrations (MPC), oxygen-isotopic ratios $\left(\delta^{18} \mathrm{O}\right)$, anion chemistry $(\mathrm{AC})$ and liquid conductivity (LC). Three $20 \mathrm{~m}$ cores, each associated with a vertical profile of pit samples, were drilled $0.5 \mathrm{~m}$ behind wall B. In addition, part of one core was sampled for beta radioactivity in order to isolate the 1965-66 horizon which resulted from atmospheric thermonuclear testing. Pits 2 and 3 were both $2 \mathrm{~m}$ deep and consisted of two $1 \mathrm{~m}$ wide perpendicular walls. Each wall was sampled for MPC, $\delta^{18} \mathrm{O}$, $\mathrm{LC}$ and $\mathrm{AC}$, and one $20 \mathrm{~m}$ core was drilled behind each wall. The visible stratigraphy of both walls in pit 3 was mapped. Densities were measured in each pit. The results from the pit and shallow-core analyses lead to the following conclusions.

The high frequency of storm events, of ten associated with winds in excess of 50 knots, leads to substantial drifting. The result is that stratigraphic features in the uppermost annual layer (e.g. crusts, mass-loss layers, hard layers, etc.) exhibit substantial vertical deviations and, on occasion, are laterally discontinuous. Substantial variation may occur over very short distances: e.g. a $2 \mathrm{~cm}$ thick melt feature pinched out over a distance of $10 \mathrm{~cm}$. Interestingly, the stratigraphy
\end{abstract}

in firn older than 1 year exhibits much less latera variation. In fact, several distinct visible stratigraphic features can be correlated among most of the shallow cores and the two deeper cores. Examples will be presented. These features provide excellent time-stratigraphic markers for cross-core comparisons. Of special interest is the presence of a major melt feature, first reported by Swiss investigators in 1983. This feature, present at four different drill sites, allows time-stratigraphic correlation and yields nearly identical 10 year accumulation rates for all four sites. Such spatial continuity means that accumulation histories reconstructed from the two deeper cores should be representative of this area.

The MPC measurements (particles per $\mathrm{ml}$ of water) are the lowest that have been measured. No measurements of atmospheric particulate concentrations are available, but the low concentrations probably result from the high annual accumulation ( $\sim 0.55 \mathrm{~m} \mathrm{a}^{-1}$, water equivalent), which dilutes the atmospheric input signal of particulates preserved in the firn. Swiss investigators reported similar results for the dilution of volcanic acids (e.g. $\mathrm{SO}_{4}{ }^{2-}$ ), which muted the conductivity signals in a $201 \mathrm{~m}$ Siple Station core. The low concentrations make particles difficult to use for dating Siple-cores. On the other hand, the low background levels of particulates may make Siple Station an excellent site for monitoring major atmospheric turbidity events (e.g. prolonged periods of desertification or volcanic activity).

The high annual accumulation leads to the excellent preservation of the $\delta^{18} \mathrm{O}$ annual signal. The annual $\delta^{18} \mathrm{O}$ signal ranges from $15 \%$ at the surface to $8 \%$ at $122 \mathrm{~m}$, so it is probable that the annual $\delta^{18} \mathrm{O}$ signal will be preserved over the entire 500 year record, allowing nearly absolute dating of the core.

The potential of a nearly absolute time-scale, coupled with detailed particulate, liquid-conductivity and $\delta^{18} \mathrm{O}$ histories, should provide the first proxy climate record from this area. This 500 year history will complement similar records anticipated from the Antarctic Peninsula $\left(\sim 73^{\circ} \mathrm{S}\right)$ and that recently constructed from the James Ross Island ice cap. A more global climatic picture of the last 500 years may be obtained when these high-resolution Antarctic ice-core records are integrated with non-polar records (e.g. the Quelccaya ice cap, Peru, and the Dunde ice cap, China) of similar quality. 